\title{
Hidden treasures: Turin's anatomy museum
}

\section{Some controversial nineteenth-century theories about brain shape and human nature are revealed by an extensive collection of neuroscience memorabilia, reports Alison Abbott.}

Cesare Lombroso's contemporaries considered him to be either a genius or a madman, or both. A professor at the University of Turin, Italy, from 1876 until his death in 1909, Lombroso was a pioneer of criminal psychology. But his unshakeable theory that criminals were born rather than made, and could be recognized by their atavistic physical characteristics, went down badly in some quarters.

His other unshakeable theory held, ironically, that genius and madness were two sides of the same degenerate coin. In 1897, at the height of his fame, Lombroso travelled to Leo Tolstoy's village in Russia to gather living proof of the theory - but the undisputed genius disappointed him by lacking the physical characteristics that Lombroso associated with madness. In turn, Tolstoy dismissed his visitor as "ingenuous and limited", and later described Lombroso's theories as a "misery of thought, of concept and of sensibility" (see Nature 409, 983; 2001). The great French novelist Émile Zola levelled that Lombroso gathered proof selectively: "like all men with preconceived theses."

The irrepressible Lombroso also had plenty of opponents back home in Turin - most notably the neuroanatomist

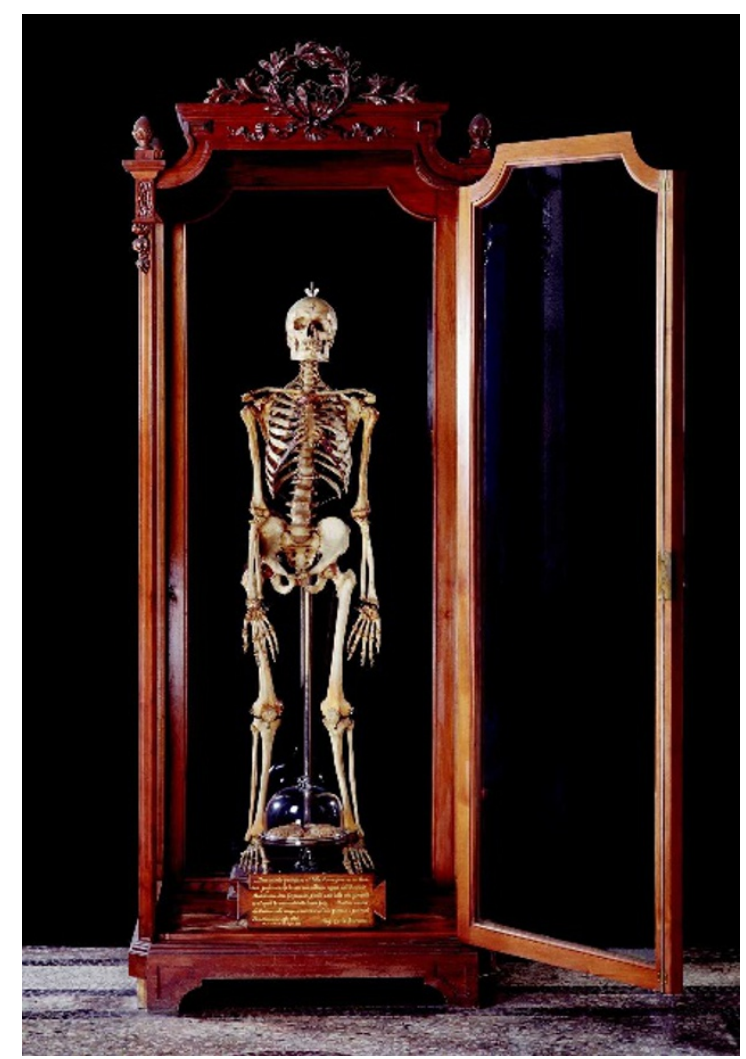

Closet genius: Giacomini's skeleton and unusually shaped brain. sulcus, which separates the primary motor cortex from the sensory cortex, is named the 'Rolando sulcus' after him. When Napoleon lost the war in 1814, Rolando returned to Turin, where he energetically applied his new learning both to his research and to the museum.

The museum has many valuable objects, but its neuroscience collection is exceptional. Aside from the staggering piles of preserved brains provided by Giacomini, there are models of the brain created throughout the nineteenth century, which show how knowledge of brain anatomy evolved extensively during this period. The collection also includes a beautiful model from 1883 which, although rather abstract, indicates for the first time that the brain is composed of nerve pathways. There is also a collection of skulls and death masks - of the great and good, and of criminals. An exquisite series of wax human embryos shows the development of the nervous system.

Giacomini, like Rolando, lived through turbulent times. He participated in the struggles to liberate parts of northern Italy from the Austrians, one of the conflicts that eventually led to the unification of Italy in 1870. During the bloody process, Turin lost its status as capital city and

nineteenth-century Turin, which considered science to be the new religion. The overcrowded glass cabinets are laid out in bays akin to side chapels, with paintings of famous anatomists - including Andreas Vesalius and Marcello Malpighi - hanging like saints in their lunettes. Four marble fonts previously contained floating anatomical preparations instead of holy water. There is even an 1897 stained-glass window depicting brain slices that Giacomini had prepared for microscopy.

During the revolutionary years of the early 1800s, when Napoleon occupied Turin, Rolando retreated to Sardinia, stopping en route to study anatomical wax modelling and scientific drawing in Florence. During his seven isolated years in Sardinia, he developed modern methods for studying the brain, integrating new data from anatomy, physiology and embryology. He is perhaps best known for recognizing the fixed patterns of sulci in the brain that fuelled the theories of Lombroso and Giacomini. The brain's deep central needed to find a new strategy for its future. It chose science, and massively expanded its university. With the burgeoning modern industries, Turin also became Italy's film capital, and museum visitors can watch the first movies of living cells made in the 1930s, including one of a chick-embryo nerve fibre reaching out to find connections.

Giacomini left his skeleton to his beloved museum when he died in 1898. At its feet sits a bell jar containing his brain, preserved according to his own method. In an 1899 lecture at Turin's academy of medicine, a colleague described its anatomical peculiarities - including the presence of a very rare double Rolando sulcus. Lombroso, listening avidly in the audience, was thrilled. Proof, he cried, of Giacomini's genius and of Lombroso's own theory.

Alison Abbott is Nature's senior European correspondent.

For more Hidden treasures, see www.nature.com/ nature/focus/hiddentreasures. in 1830 . The design is church-like, in defer- 